\title{
Bullous lung disease and neurofibromatosis type-1
}

\author{
E. Nardecchia ${ }^{1}$, L. Perfetti2, M. Castiglioni ${ }^{1}$, \\ D. Di Natale1, A. Imperatori1, N. Rotolo1
}

ABSTRACT: Bullous lung disease and neurofibromatosis type-1. E. Nardecchia, L. Perfetti, M. Castiglioni, D. Di Natale, A. Imperatori, N. Rotolo.

Lung interstitial diseases and bullae are described as possible complications of neurofibromatosis type-1 (NF-1), a genetic disorder inherited as a autosomal-dominant trait. We report the case of a 16-year-old male non-smok- er with NF-1, who presented with pneumothorax caused by ruptured lung bullae. The case of this young patient, successfully treated by video-assisted thoracoscopic resection of bullae, supports the concept that pulmonary alterations may be part of the NF-1 syndrome, rather than as an unrelated complication.

Monaldi Arch Chest Dis 2012; 77: 2, 105-107.

Keywords: Neurofibromatosis, Pneumothorax, Emphysema, Lung bullae.

I Department of Surgical and Morphological Sciences, Thoracic Surgery Unit, Varese University Hospital, University of Insubria, Varese;

2 Respiratory Unit, Varese University Hospital, University of Insubria, Varese, Italy.

Correspondence: Nicola Rotolo, Department of Surgical and Morphological Sciences, Thoracic Surgery Unit, Varese University Hospital, University of Insubria, Via Guicciardini 9, 21100 Varese, Italy; e-mail: nicola.rotolo@uninsubria.it

\section{Introduction}

Von Recklinghausen's disease (VRD), also known as neurofibromatosis-1 (NF-1) is an autosomal-dominant disease that occurs with a prevalence of 1:2500-3000, independently from ethny and gender. Approximately 50\% of cases are due to mutation of chromosome 17. Clinically, NF-1 is recognised by the presence of numerous "café-aulait" skin macules, but $25 \%$ of affected patients develop multiple cutaneous and central nervous system (CNS) tumors that are histologically characterized as neurofibroma, pheochromocytoma or fibrosarcoma [1, 2].

To establish the diagnosis of NF-1, molecular definition of the disease is not necessary. Clinical criteria for the diagnosis of NF-1 were defined in 1997 and confirmed in 2007 [3]; two or more of the following criteria must be met:

- six or more café-au-lait spots $>5 \mathrm{~mm}$ in diameter before puberty, or $>15 \mathrm{~mm}$ after puberty; - two or more typical neurofibromas of any type, or one plexiform neurofibroma;

- frackles/hyperpigmentation spots in area inaccessible to sunlight (axilla, groin);

- two ore more iris hamartomas (Lisch nodules); - typical bone abnormalities (see below);

- first-degree relative meeting the above criteria.

The thoracic manifestations of NF-1 are most commonly cutaneous, but they can also be skeletal and pulmonary [4]. The most common thoracic skeletal manifestations of NF-1 involve the spine and ribs. Characteristic deformities of the ribs in- clude well-marginated erosions of one or more ribs, and the separation of adjacent ribs due to plexiform neurofibromas. Spinal abnormalities can present as kyphoscoliosis, posterior scalloping of the vertebral bodies and enlargement of neural foramina [2]. Lung manifestations, that usually include interstitial lung disease (ILD) and thinwalled bullae, are reported in as many as $10-20 \%$ of adult patients with NF-1. Although these findings may be incidental, sometimes patients present with dyspnea that may also result from lung mesenchymal abnormalities [5]. Pulmonary fibrosis is usually bilateral and simmetric, predominantly basal [6]. Typically, ILD occurs in association with bullae that are thin-walled, located in the upper lobes, and usually asymmetric $[1,6]$.

\section{Case report}

A 16-year-old male non-smoker, with ectomorph body build, affected by VRD was referred to our hospital complaining of chest pain and palpitations. His vitals signs and haemoglobin oxygen saturation were normal. Chest X-ray examination showed left pneumothorax (fig. 1). The patient past medical history was unremarkable, except for the diagnosis of VRD made in 2004. This diagnosis was based on physical examination, which revealed multiple (>6) large café-au-lait macules on the chest skin and in cutaneous areas of the abdomen usually not exposed to sunlight (fig. 2). Other clinical manifestations of VRD (CNS, skeletal, neurological) were absent. The pneumothorax 


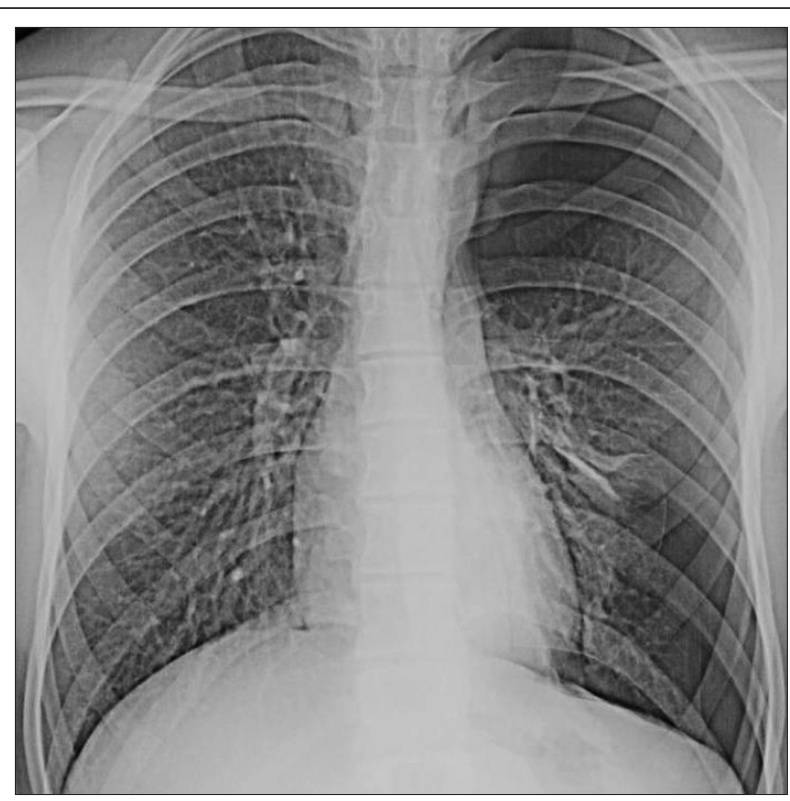

Fig. 1. Chest X-ray exam on admission, showing left-sided pneumothorax.

was treated by tube drainage of the left pleural space. Since pulmonary air leakage persisted for several days, high-resolution computed tomography (HRCT) of the chest was obtained. Chest scans revealed bilateral apical lung bullae, with diameter up to $1.5 \mathrm{~cm}$ (fig. 3). Surgical treatment of persistent pneumothorax was decided. With a left 3-port video-thoracoscopic approach, the apical lung bullae were resected and successful pleurodesis was obtained by partial parietal pleurectomy. Histological examination of the resected pulmonary bullae revealed emphysematous parenchyma with sub-pleural bullae. The post-operative course was uneventful and after seven days the patient was discharged in good condition. At 30-day follow-up the patient was asymptomatic.

\section{Discussion}

NF-1 is a neurogenetic disorder with widespread involvement of neuroectodermal and mesodermal tissues [7, 8]. Lung involvement consisting of ILD and/or bullae is not infrequent in the context of NF-1. The association between NF-1 and ILD was first reported in 1963 by Davies [9], and several authors described coexisting lung diseases in $10-20 \%$ of patients with NF-1 $[5,9]$. A review of the pertinent literature revealed many different types of lung lesions detected by radiological imaging in VRD patients, as summarized in table 1. Associated pulmonary manifestations most commonly include bilateral fibrosis with basal predominance, associated or not with thin-walled bullae that typically occur in the upper lobes $[1,2,5$, 9-16]. Less frequently intra thoracic tumour and cystic disorders have been described [1, 2, 5]. However, it is uncertain whether the development of ILD is a peculiar phenotypic manifestation of NF-1. A recent article questioned such association, reporting that the evidence supporting a causative relationship between $\mathrm{NF}-1$ and interstitial diseases is poor, and suggested that the latter are mainly

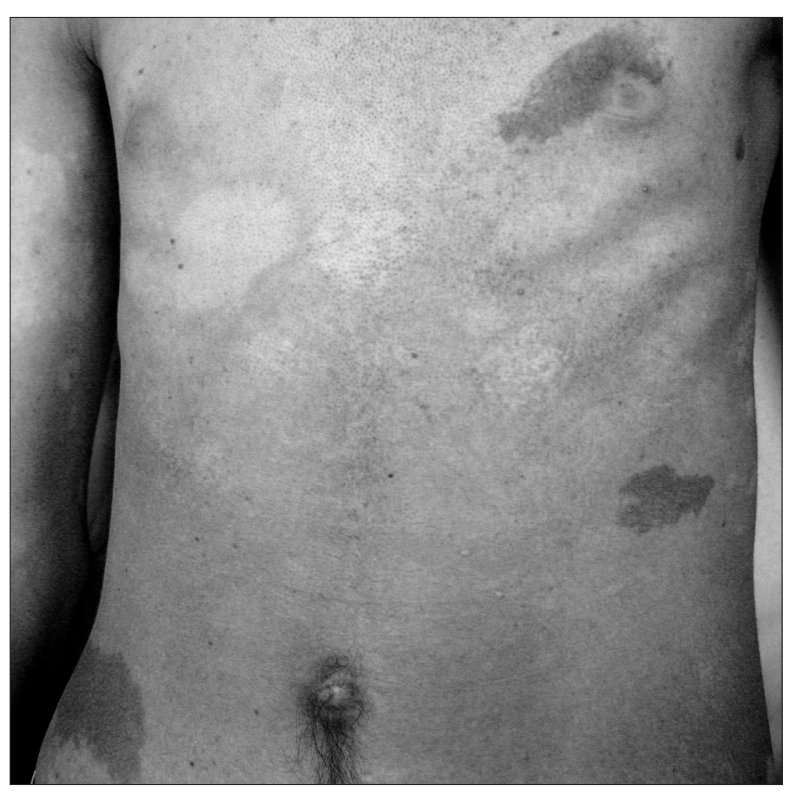

Fig. 2. Café-au-lait cutaneous macules on the chest and abdomen.

smoking-induced manifestations [15]. However, Zamora et al. proposed that NF-1 in association with ILD represents a distinct clinical entity [1]. The pathogenesis of ILD in patients with NF-1 is uncertain. Patchefsky et al. suggested that pulmonary fibrosis in NF-1 may be determined by increased deposition of collagen in the lung, causing a fibrotic environment [12]. Fabricant et al. postulated a similar pathogenetic mechanism, attributing the cause of ILD to myofibroblast activation by increased nerve growth factor levels in NF-1 patients [17].

In our case, the patient had a pre-existing clinical diagnosis of NF-1, documented by café-aulait macules on the chest and lower abdomen skin, and presented with pneumothorax caused by ruptured lung bullae. His chest HRCT showed bilateral apical lung bullae, without signs of fibrosis, and histology of the resected bullous parenchyma revealed emphysematous lung. Differently from previous reports of lung bullous disease associated with VRD, that occurred after the fourth decade of life $[11,13,14,16]$, the case here described occurred in a non-smoker young male, and supports the concept that NF-1 with bullous

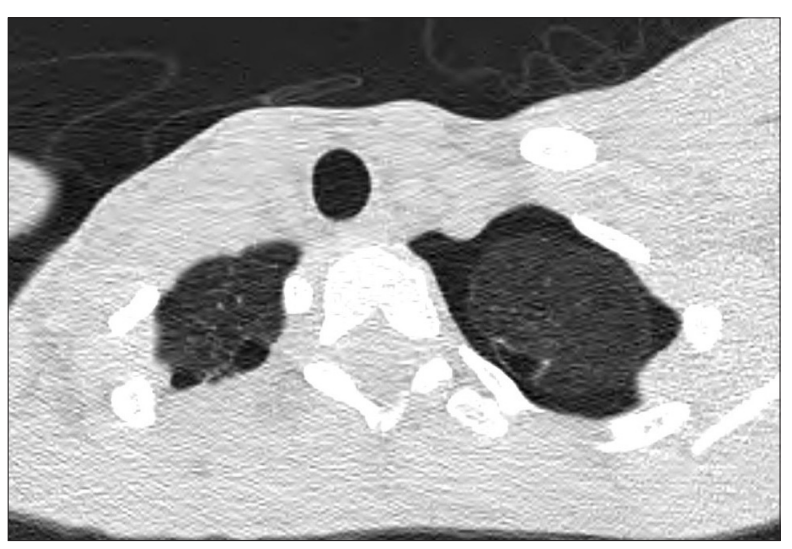

Fig. 3. High resolution computed tomography scan of the chest, showing pulmonary bullous disease bilaterally, and left-sided pneumothorax. 
Table 1. - Chest radiographic findings of lung abnormalities associated with NF-1

\begin{tabular}{|c|c|c|c|c|}
\hline Author & $\begin{array}{l}\text { Cases of thoracic } \\
\text { abnormalities } \\
\text { in VRD* patients }\end{array}$ & $\begin{array}{l}\text { Radiographic } \\
\text { appearance }\end{array}$ & $\begin{array}{l}\text { Predominant } \\
\text { lung site }\end{array}$ & $\begin{array}{l}\text { Respiratory } \\
\text { symptoms }\end{array}$ \\
\hline Davies PDB, 1963 [9] & 9 & Mottled opacities & Lower lobe & Breathlessnes, dyspnoea \\
\hline Israel-Asselain R, 1965 [10] & 2 & $\begin{array}{l}\text { Reticular/linear opacities } \\
\text { Nodular opacities }\end{array}$ & $\begin{array}{l}\text { Upper lobe } \\
\text { Lower lobe }\end{array}$ & Dyspnoea, cough \\
\hline Massaro D, 1966 [11] & 20 & $\begin{array}{c}\text { Bullae } \\
\text { Mottled and linear infiltrate }\end{array}$ & $\begin{array}{l}\text { Upper lobe } \\
\text { Diffuse }\end{array}$ & Not Available \\
\hline Patchefsky A, 1973 [12] & 1 & Diffuse interstitial infiltrations & Lower lobe & Dyspnoea \\
\hline Volpini E, 1995 [13] & 1 & Severe bullous emphysema & Upper lobe & Breathlessnes \\
\hline Yokoyama A, 1997 [14] & 1 & Bullae and acinar emphysema & Upper lobe & No \\
\hline Rossi SE, 1999 [2] & Not Available & $\begin{array}{l}\text { Thin-walled bullae } \\
\text { Lung fibrosis }\end{array}$ & $\begin{array}{l}\text { Upper lobe } \\
\text { Lower lobe }\end{array}$ & Not Available \\
\hline Ryu JH, 2005 [15] & 22 & $\begin{array}{c}\text { Pulmonary nodules } \\
\text { Cystic airspace } \\
\text { Bullae } \\
\text { Interstitial infiltrate }\end{array}$ & Not Available & Not Available \\
\hline Zamora AC, 2007 [1] & 64 & $\begin{array}{l}\text { Thin-walled bullae } \\
\text { Linear opacities } \\
\text { Bullous emphysema } \\
\text { Thin-walled cyst }\end{array}$ & $\begin{array}{l}\text { Upper lobe } \\
\text { Lowe lobe } \\
\text { Upper lobe } \\
\text { Upper lobe }\end{array}$ & Dyspnoea, cough, chest pain \\
\hline Oikonomou A, 2010 [5] & 6 & Thin-walled cyst & Upper lobe & No \\
\hline Zanobetti M, 2012 [16] & 1 & Small thin-walled cyst & Lower lobe & Dyspnoea, cough \\
\hline
\end{tabular}

lung disease may be a distinct clinical entity, unrelated to smoking $[1,5,9]$.

\section{References}

1. Zamora AC, Collard HR, Wolters PJ, Webb WR, King TE. Neurofibromatosis associated lung disease: a case series and literature review. Eur Respir J 2007; 29: 210-14.

2. Rossi SE, Erasmus JJ, Page McAdams H, Donelly LF. Thoracic manifestations of neurofibromatosis-I. Am J Roentgenol 1999; 173: 1631-8.

3. Ferner RE, Huson SM, Thomas $\mathrm{N}$ et al. Guidelines for the diagnosis and management of individuals with neurofibromatosis 1. J Med Genet 2007; 44: 81-88.

4. Riccardi VM. Von Recklinghausen neurofibromatosis. N Engl J Med 1981; 305: 1617-27.

5. Oikonomou A, Vadikolias K, Birbilis T, Bouros D, Prassopoulos P. HRCT findings in the lungs of non smokers with neurofibromatosis. Eur J Radiol 2011; 80: 520-23.

6. Miyamoto K. Pulmonary manifestations in Von Recklinghausen's disease. Intern Med 1997; 36: 381.

7. Arun D, Gutmann DH. Recent advances in neurofibromatosis type 1. Curr Opin Neurol 2004; 17: 101-5.

8. Karmes PS. Neurofibromatosis: a common neurocutaneous disorder. Mayo Clin Proc 1998; 73: 1071-76.

9. Davies PDB. Diffuse pulmonary involvement in Von Recklinghausen's disease: a new syndrome. Thorax 1963; 18: 198.

10. Israel-Asselain R, Chebat J, Sors CH, Basset F, Le Rolland A. Diffuse interstitial pulmonary fibrosis in a mother and son with von Recklinghausen's disease. Thorax 1965; 20: 153-57.

11. Massaro D, Katz S. Fibrosing alveolitis: its occurrence, roentgenographic and pathologic features in von Recklinghausen's neurofibromatosis. Am Rev Respir Dis 1966; 93: 934-42.

12. Patchefsky AS, Atkinson WG, Hoch WS, Gordon G, Lipshitz HI. Interstitial pulmonary fibrosis and von Recklinghausen's disease. An ultrastructural and immunofluorescent study. Chest 1973; 64: 459-64.

13. Volpini E, Convertino G, Fulgoni P, Savasta S, Vitulo P. Pulmonary changes in a man affected by von Recklinghausen's disease. Monaldi Arch Chest Dis 1996; 51: 123-24.

14. Yokoyama A, Kohno N, Sakai K, Kondo K, Hirasawa Y, Hiwada K. Distal acinar emphysema and interstitial pneumonia in a patient with von Recklinghausen's disease: five-year observation following quitting smoking. Intern Med 1997; 36: 413-16.

15. Ryu JH, Parambil JG, McGrann PS, Aughenbaugh GL. Lack of evidence for an association between neurofibromatosis and pulmonary fibrosis. Chest 2005; 128 : 2381-86.

16. Zanobetti M, Del Taglia B, Conti A, Innocenti F, Pini $\mathrm{R}$. Chest ultrasonography to detect lung involvement in von Recklinghausen's disease. Intern Emerg Med 2012; DOI 10.1007/s11739-012-0779-8.

17. Fabricant RN, Todaro GJ. Increased serum levels of nerve growth factor in von Recklinghausen's disease. Arch Neurol 1981; 38: 401-5. 